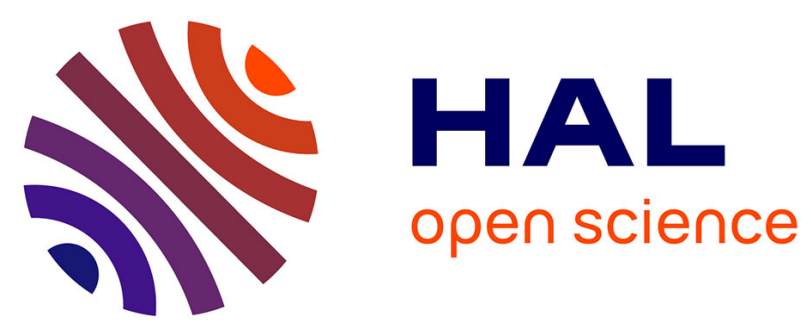

\title{
Use of a non-adherent cell culture system for testing the effect of 2',3'-dideoxyinosine against Cryptosporidium parvum
}

\author{
Philippe Lawton, Carine Hejl, Marie-Elisabeth Sarciron, Roselyne \\ Mancassola, Muriel Naciri, Anne-Françoise Pétavy
}

\section{To cite this version:}

Philippe Lawton, Carine Hejl, Marie-Elisabeth Sarciron, Roselyne Mancassola, Muriel Naciri, et al.. Use of a non-adherent cell culture system for testing the effect of 2',3'-dideoxyinosine against Cryptosporidium parvum. FEMS Microbiology Letters, 1999, 176 (1), pp.235-240. 10.1111/j.15746968.1999.tb13667.x . hal-02110959

\section{HAL Id: hal-02110959 \\ https://univ-lyon1.hal.science/hal-02110959}

Submitted on 26 Apr 2019

HAL is a multi-disciplinary open access archive for the deposit and dissemination of scientific research documents, whether they are published or not. The documents may come from teaching and research institutions in France or abroad, or from public or private research centers.
L'archive ouverte pluridisciplinaire HAL, est destinée au dépôt et à la diffusion de documents scientifiques de niveau recherche, publiés ou non, émanant des établissements d'enseignement et de recherche français ou étrangers, des laboratoires publics ou privés. 


\title{
Use of a non-adherent cell culture system for testing the effect of 2',3'-dideoxyinosine against Cryptosporidium parvum
}

\author{
Philippe Lawton ${ }^{\mathrm{a}, *}$, Carine Hej1 ${ }^{\mathrm{a}}$, Marie-Elisabeth Sarciron ${ }^{\mathrm{a}}$, \\ Roselyne Mancassola ${ }^{b}$, Muriel Naciri ${ }^{b}$, Anne-Françoise Petavy ${ }^{a}$ \\ a Département Pharmaceutique de Parasitologie et Mycologie Médicale, Faculté de Pharmacie, Université Claude-Bernard, \\ F-69373 Lyon Cedex 08, France \\ b INRA, Laboratoire de Pathologie Aviaire et de Parasitologie, Nouzilly, France
}

Received in revised form 12 May 1999; accepted 16 May 1999

\begin{abstract}
The in vitro cultivation of Cryptosporidium parvum in the non-adherent cell line THP-1 was evaluated for its capability as a useful additional model to investigate the effect of drugs on this parasite. The purine analog antiviral $2^{\prime}, 3^{\prime}$-dideoxyinosine (ddI) was evaluated and compared to the reference molecule paromomycin in sequential 24 hour experiments beginning at 24 and 72 hour post-infection. The ability of this technique to evaluate the various parasite stages showed that ddI displayed a dosedependent efficacy especially on the trophozoite and sexual stages. Paromomycin displayed a lower efficacy than previously reported. Both drugs induced a decrease in the number of multiparasitized cells. These results indicate that the purine salvage pathway should be a key chemotherapeutic target against C. parvum.
\end{abstract}

Keywords: Cryptosporidium parvum; In vitro; THP-1 cell; 2',3'-dideoxyinosine; Paromomycin

\section{Introduction}

Cryptosporidium parvum is an enteric parasite protozoan that causes life-threatening diarrheas in immunocompromised hosts. Despite real successes $[1,2]$, it is still a difficult parasite to maintain in vitro and neither a continuous culture system or a satisfactory in vivo model are currently available. We

* Corresponding author. Tel.: +33478 777277 ; Fax: +3347877 71 58; E-mail: lawton@univ-lyon1.fr have successfully developed an in vitro culture model using the non-adherent myelomonocytic human cell line THP-1 which provides an enhanced versatility and allows the determination of the various parasitic stages [3]. We used this system to test $2^{\prime}, 3^{\prime}$-dideoxyinosine (ddI), a purine analog active against HIV and Toxoplasma gondii in vitro and in vivo [4,5]. Paromomycin, an aminoglycoside reported to exert some activity against C. parvum in vitro [6-8], in animal models [9-11] and AIDS patients [12] was used as a positive control. 


\section{Materials and methods}

\subsection{Cells}

The myelomonocytic cell line THP-1 (ECACC \#88081201, Sophia Antipolis, France) was continuously maintained in RPMI 1640 (Sigma, L'Isle d'Abeau, France) supplemented with 25 mM HEPES (Sigma H-9136), $200 \mathrm{U} \mathrm{ml}^{-1}$ of penicillin, $200 \mu \mathrm{g}$ $\mathrm{ml}^{-1}$ of streptomycin (Sigma P-0781) and 10\% fetal calf serum (DAP, Vogelgrun, France) at $37^{\circ} \mathrm{C}$ in a $5 \% \mathrm{CO}_{2}$ moist atmosphere. The cell suspension was diluted once a week when the cell density reached about $1 \times 10^{6} \mathrm{ml}^{-1}$.

\subsection{Parasites}

C. parvum oocysts were passaged in neonatal calves (INRA, Nouzilly, France) and purified as previously described [3] with the following modifications: after removing the fat by ether treatment, the fecal suspension was washed $3 \times$ for $15 \mathrm{~min}$ at $1500 \times g$ in cold $\left(4^{\circ} \mathrm{C}\right)$ tap water. The pooled fecal pellet was allowed to sediment in $25 \mathrm{ml}$ cold tap water for $2 \mathrm{~h}$ and again for $1 \mathrm{~h}$ at $4^{\circ} \mathrm{C}$ in order to remove the larger debris. The supernatants were pooled, centrifuged $15 \mathrm{~min}$ at $1500 \times \mathrm{g}$ and suspended in $10 \mathrm{ml}$ tap water. This suspension was carefully layered on the top of a chilled $\left(4^{\circ} \mathrm{C}\right)$ Sheather solution diluted 1:2(v/v) and centrifuged at $1500 \times g$ for $10 \mathrm{~min}$. The white layer at the top of the sucrose solution was removed and washed $3 \times$ in tap water. The oocyst suspension was kept at $4^{\circ} \mathrm{C}$ in $2.5 \%(\mathrm{w} / \mathrm{v})$ $\mathrm{K}_{2} \mathrm{Cr}_{2} \mathrm{O}_{7}$ until required.

\subsection{Percoll solutions}

Sterile isotonic Percoll was prepared by mixing one part of $10 \times$ Hanks balanced salts solution (HBSS, Sigma H-1641) with nine parts Percoll (Sigma P-4937) and stored at $4^{\circ} \mathrm{C}$. Solutions of $30 \%$ and $60 \%(\mathrm{v} / \mathrm{v})$ were made by diluting the isotonic Percoll stock solution with RPMI 1640. The solutions were stored at $4^{\circ} \mathrm{C}$ and prewarmed at $37^{\circ} \mathrm{C}$ prior to use.

\subsection{Infection of cells with C. parvum}

Prior to infection, the THP-1 cells were collected and pelleted for $4 \mathrm{~min}$ at $160 \times \mathrm{g}$. They were diluted in culture medium and kept in the incubator until required. The oocysts (approx. $30 \times 10^{6}$ ) were washed $3 \times$ and were suspended in $1 \mathrm{ml}$ cold tap water. They were surface-sterilized with a $1.25 \%$ sodium hypochlorite solution on ice for $5 \mathrm{~min}$, centrifuged at $1500 \times \mathrm{g}$ for $7 \mathrm{~min}$ and washed once with cold RMPI 1640. The treated oocysts were incubated for $5 \mathrm{~min}$ in $1 \mathrm{ml}$ excystation medium $(0.25 \%$ trypsin, $0.75 \%$ sodium taurocholate in $\mathrm{PBS}$ ) at $37^{\circ} \mathrm{C}$ in order to facilitate excystation, and washed once in prewarmed RPMI 1640. The THP-1 cell suspension was then mixed with the oocyst pellet (oocyst to cell ratio $1: 1$ to $3: 1$ ) and carefully layered on top of the $60 \%$ Percoll solution and centrifuged $10 \mathrm{~min}$ at $1500 \times g$. Excystation was allowed to proceed at $37^{\circ} \mathrm{C}$ for 1.5 to $3 \mathrm{~h}$ in the parasites-cells layer at the interface between the Percoll solution and the medium. This layer was then retrieved with a Pasteur pipette and washed once in RPMI 1640 for $9 \mathrm{~min}$ at $600 \times g$. After dilution in culture medium, the parasitized cells were layered on top of a $30 \%$ Percoll solution and centrifuged at $1500 \times \mathrm{g}$ for $10 \mathrm{~min}$. Most of the cell debris and oocysts shells stayed on top of the Percoll-medium interface. The pellet was subsequently washed once at $600 \times g$ and $2 \times$ at $160 \times g$ as above and distributed in a 24-well Falcon microplate (Becton-Dickinson, Meylan, France) at an approximate density of $4 \times 10^{6}$ cells ml ${ }^{-1}$ under reduced oxygen in a candle jar. The medium was replaced twice a day until used for the experiments.

\subsection{Drugs}

Paromomycin sulfate (Sigma P-5057) was dissolved in RMPI 1640 as a $100 \mathrm{mg} \mathrm{ml}^{-1}$ stock solution. 2', 3'-dideoxyinosine (ddI) was kindly provided by Bristol Myers Squibb (Paris, France) and was dissolved at a $20 \mathrm{mg} \mathrm{m}^{-1}$ stock solution in RPMI 1640. The stock solutions were aliquoted and stored at $-20^{\circ} \mathrm{C}$.

\subsection{Inhibition studies}

The experiments were performed on $24 \mathrm{~h}$ and $72 \mathrm{~h}$ old cultures. They were washed $3 \times$ for $5 \mathrm{~min}$ at $160 \times g$ in RMPI 1640 before incubation with the drugs. Prior to use, the stock solutions were diluted 
$1: 100$ in culture medium to give concentrations of $1 \mathrm{mg} \mathrm{ml}^{-1}$ for paromomycin and $200 \mu \mathrm{g} \mathrm{ml}^{-1}$ for ddI. When needed, serial dilutions (200 to $25 \mu \mathrm{g}$ $\mathrm{ml}^{-1}$ ) were made in complete medium and distributed under $100 \mu 1$ in a 96-well Nunclon microplate (Nunc, Denmark). Control wells received $100 \mu 1$ of culture medium. In each well, $100 \mu$ of the washed parasitized cell suspension (final volume: $200 \mu \mathrm{l}$; concentration: $4 \times 10^{6} \mathrm{ml}^{-1}$ ) were added, mixed and incubated in a candle jar for $24 \mathrm{~h}$ at $37^{\circ} \mathrm{C}$. The final concentrations were 100 to $12.5 \mu \mathrm{g} \mathrm{ml}^{-1}$ for ddI and $500 \mu \mathrm{g} \mathrm{ml}^{-1}$ for paromomycin. Each concentration was tested in triplicate.

\subsection{Evaluation of parasite growth}

The content of the wells was thoroughly mixed and centrifuged for $1 \mathrm{~min}$ in microtubes at 15000 revs $\mathrm{min}^{-1}$ in a Beckman Avanti centrifuge. Thin smears were made, fixed in $100 \%$ methanol and stained with $20 \%$ Giemsa and $1 \%$ Alcian blue as previously described [3]. At least 1000 cells were counted with an oil immersion $\times 100$ objective. The percentage of cells infected with the various development stages of the parasite was assessed, as well as the number of multiparasitized cells. The inhibition percentages were calculated using the following formula: $100-[\%$ of infected cells in the treated wells $/ \%$ of infected cells in the control wells] for the relevant parasite stages. The Student's $t$-test was used to assess the statistical significance of the results.

\section{Results and discussion}

The in vitro cultivation of $C$. parvum in the nonadherent THP-1 cells allowed an easy assessment of invasion and distribution of cell infection. Thus a good reproducibility and a standardization of the technique could be easily achieved. The use of the Percoll gradient stage provided an enhanced availability of the host cells for the excysting oocysts and a more efficient elimination of dead cells and shells. In addition, the treated and control wells originated from the same parasitized cell suspension, ensuring that there was no discrepancy in the invasion rates. This technique also allowed the sequential investigation of the effects of the drugs on various portions of the cycle of $C$. parvum in an already established infection: the experiments were performed at $24 \mathrm{~h}$ post-infection (p.i.) when the asexual cycle is predominant, and at $72 \mathrm{~h}$ p.i., when sexual stages appear. The use of the Giemsa-Alcian blue stain allowed the enumeration of parasitized cells, the evaluation of those bearing more than one parasite and the assessment of alterations of the host cells and parasites. Finally, the reproducibility of our technique and the toxicity of the compounds could be controlled with a hemacytometer.

We have recently shown that the purine analog 2',3'-dideoxyinosine (ddI) was highly active against $T$. gondii cultured in THP-1 cells and suggested the purine salvage pathway of this parasite as a promising chemotherapeutic target $[4,5]$. As an Apicomplexan, $C$. parvum possesses some different metabolic pathways [13] and also lacks a de novo purine synthesis, as reported recently [14]. Paromomycin was used as a positive control because it has been consistently described as one of the few, if not the only molecule active against $C$. parvum.[6-12]. The dose of $500 \mu \mathrm{g} \mathrm{ml}^{-1}$ was chosen since it has been previously reported that in $48 \mathrm{~h}$ tests, $100 \mu \mathrm{g} \mathrm{ml}^{-1}$ produced a $69 \%$ inhibition in HCT-8 cells [15] and recently, a $72 \%$ inhibitory activity was obtained at 500 $\mu \mathrm{g} \mathrm{ml}^{-1}$ in vitro [16]. In addition, preliminary experiments had shown that higher doses were not more efficient. It was also of interest to determine which stages were sensitive, since this molecule does not penetrate into the cells.

There was no significant difference between the controls and the treated cultures $\left(4.1 \pm 0.1 \times 10^{6}\right.$ $\mathrm{ml}^{-1}$ ), showing that neither drug had any influence on the growth rate or number of the THP-1 cells. The effect of ddI on the various stages at $24 \mathrm{~h}$ p.i. was dose-dependent. However, the effect rapidly reached a maximum inhibition of $14.9 \pm 9.4 \%$ at $100 \mu \mathrm{g} \mathrm{ml}^{-1}$ and only slightly increased with the dosage (Fig. 1). It is noteworthy that despite this rather low inhibition, the trophic stages were reduced (26.1 $\pm 6.8 \%)$, as well as the number of multiparasitized cells $(33.8 \pm 5.4 \%)$. The reference molecule paromomycin had a moderate overall activity $(12.7 \pm 5.7 \%)$, at the onset of parasite growth. However, the number of cells bearing more than one parasite was significantly decreased $(P<0.05)$ (Fig. 2). When added to 3 day cultures, $100 \mu \mathrm{g} \mathrm{ml}^{-1} \mathrm{ddI}$ 


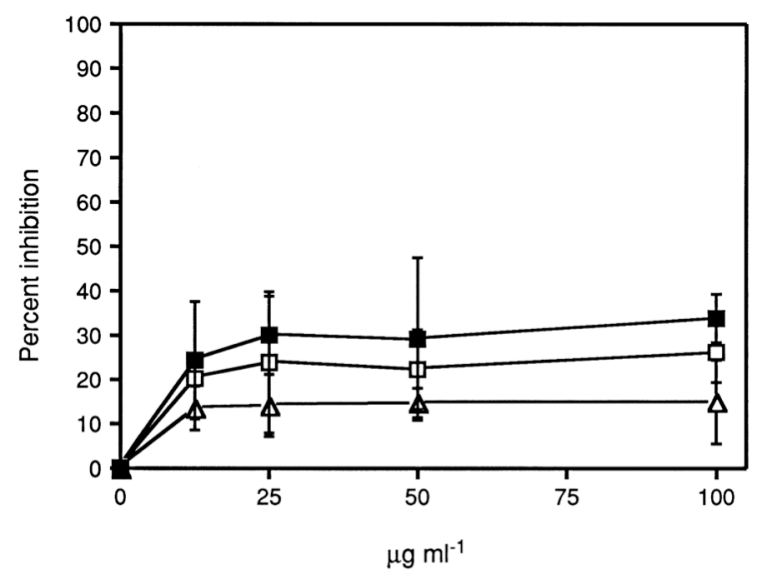

Fig. 1. Dose-response curve for ddI on the in vitro development of Cryptosporidium parvum in THP-1 cells. The drug was incubated for $24 \mathrm{~h}$ with $24 \mathrm{~h}$ old cultures. Trophozoites ( $\square$ ), multiparasitized cells $(\boldsymbol{\square})$, total $(\Delta)$. Results are expressed as percent inhibition of the control $(5.82 \pm 1.12 \%$ of parasitized cells). $N=9$ for each data point, from three separate experiments with triplicate values.

triggered a marked decrease in the number of sexual stages $(73.3 \pm 10.4 \%)$ while paromomycin displayed a similar effect as at $24 \mathrm{~h}$ p.i. (Fig. 3). This correlates with paromomycin not penetrating into the host cells and hence, displaying an effect restricted to the extracellular parasites, reducing their subsequent maturation but not their invasion capability. A recent report [7] showed that paromomycin could be active

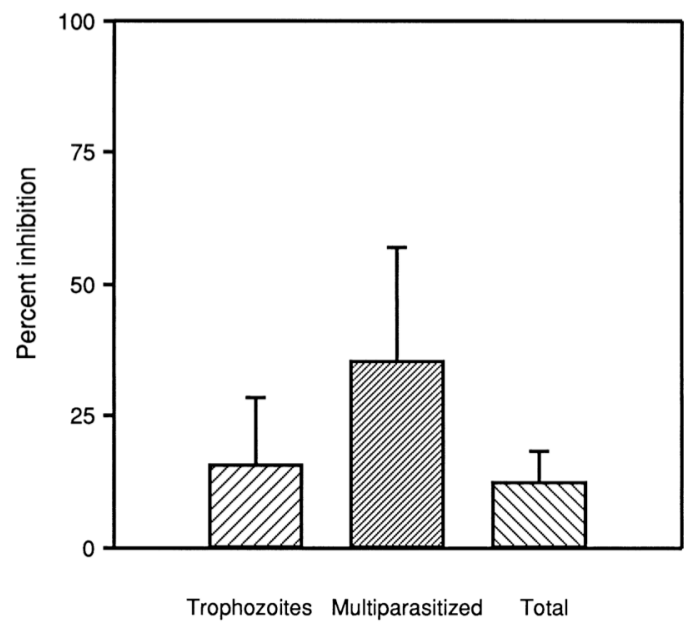

Fig. 2. Activity of $500 \mu \mathrm{g} \mathrm{ml}^{-1}$ of paromomycin on the development of Cryptosporidium. parvum in THP-1 cells in $24 \mathrm{~h}$ old cultures. Data originate from the same experiments as Fig. 1.

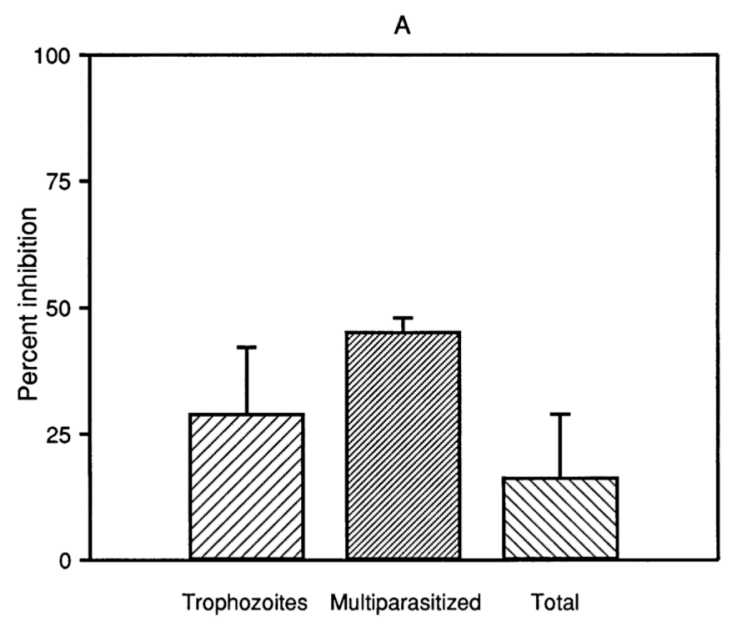

B

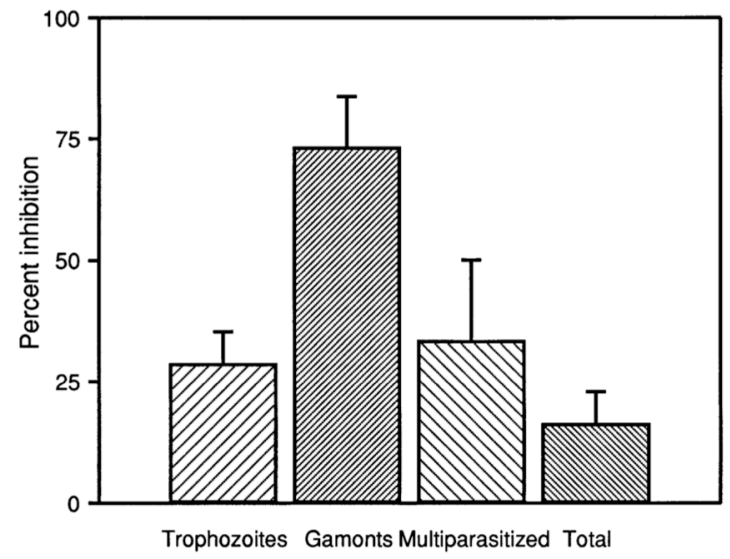

Fig. 3. Inhibitory activity of $500 \mu \mathrm{g} \mathrm{ml}^{-1}$ of paromomycin (A) and of $100 \mu \mathrm{g} \mathrm{ml}^{-1} \mathrm{ddI}$ (B) on the various stages of Cryptosporidium parvum in THP-1 cells in 3 day cultures. The drugs were incubated for $24 \mathrm{~h}$. Results are expressed as percent inhibition of the control $(2.43 \pm 0.52 \%$ of parasitized cells). $N=9$ for each data point, from three separate experiments with triplicate values.

against C. parvum without entering the host cell cytoplasm. Its moderate efficacy in $24 \mathrm{~h}$ tests in our model appears to correlate with some observed effects in vivo, especially its inefficacy reported by Brasseur et al. in a rat model [17].

Our results with ddI are consistent with an effect on the salvage pathway of the $C$. parvum purine metabolism taking place throughout the entire cycle and producing a decrease in the total parasitemia, especially when the cycle shifts towards the sexual forms. This molecule is taken up by the monocyte/ macrophage populations, especially the resting cells 
$[18,19]$ where its metabolite ddATP is found, as well as ddI-derived radioactivity incorporated into the cell DNA and RNA pool [20]. In contrast to $T$. gondii where low concentrations were rapidly active [4,5], the lower inhibition of C. parvum probably reflects the different metabolic activity of this parasite. Furthermore, ddI must penetrate into the THP1 cells where it may be metabolized before entering the parasite, thus reducing its subsequent inhibitory activity.

For both molecules, no significant decrease in the undifferentiated parasites could be seen compared to the control, suggesting that neither drug was active against the invasion capability of the parasite. In our system, the number of multiparasitized cells depends on both the cell density and the percentage of infection. In the present study, the multiparasitized cells usually harbored two parasites. The lower numbers of multiparasitized cells in the treated cultures are thus correlated to the global number of parasites and account for an about 10\% higher inhibition.

Cultivation of $C$. parvum in THP-1 cells provides a useful additional tool for the evaluation of chemotherapeutic agents. The ability to distinguish between the parasite stages also allows insights into the mode of action of the compounds. One of its major restrictions however, is the limitation of the test duration to $24 \mathrm{~h}$, but preliminary experiments with ddI for 6 consecutive days did not yield improved results. A recent report showed that some nucleoside analogs of pyrimidine structure displayed interesting activities against $C$. parvum in vitro [21]. Our results confirm the promising effects of purine analogs, indicating that the purine salvage pathway might be a key chemotherapeutic target against $C$. parvum infection.

\section{Acknowledgements}

We wish to thank Dr. Philippe Ngo Van (Bristol Myers Squibb, Paris, France) for the kind supply of ddI.

\section{References}

[1] Current, W.L. and Haynes, T.B. (1984) Complete development of Cryptosporidium in cell culture. Science 224, 603-605.
[2] Upton, S.J., Tilley, M. and Brillhart, D.B. (1995) Effects of select medium supplements on in vitro development of Cryptosporidium parvum in HCT-8 cells. J. Clin. Microbiol. 33, 371-375.

[3] Lawton, Ph., Naciri, M., Mancassola, R. and Petavy, A.-F. (1996) Cultivation of Cryptosporidium parvum in a non-adherent human monocytic cell line. J. Microbiol. Methods 27, 165173.

[4] Sarciron, M.E., Lawton, Ph., Saccharin, C., Petavy, A.-F. and Peyron, F. (1997) Effects of 2',3'-dideoxyinosine on Toxoplasma gondii cysts in mice. Antimicrob. Agents Chemother. 41, 1531-1536.

[5] Sarciron, M.E., Lawton, Ph., Petavy, A.-F. and Peyron, F. (1998) Alterations of Toxoplasma gondii induced by $2^{\prime}, 3^{\prime}-\mathrm{di}-$ deoxyinosine in vitro. J. Parasitol. 84, 1055-1059.

[6] Marshall, R.J. and Flanigan, T.P. (1992) Paromomycin inhibits Cryptosporidium infection of a human enterocyte cell line. J. Infect. Dis. 165, 772-774.

[7] Griffiths, J.K., Balakrishnan, R., Widmer, G. and Tzipori, S. (1998) Paromomycin and geneticin inhibit intracellular Cryptosporidium parvum without trafficking through the host cell cytoplasm: implications for drug delivery. Infect. Immun. 66, 3874-3883.

[8] You, X., Schinazi, R.F., Arrowood, M.J., Lejkowski, M., Juodawlkis, A.S. and Mead, J.R. (1998) In-vitro activities of paromomycin and lasalocid evaluated in combination against Cryptosporidium parvum. J. Antimicrob. Chemother. 41, 293296.

[9] Healey, M.C., Yang, S., Rasmussen, K.R., Jackson, M.K. and Du, C. (1995) Therapeutic efficacy of paromomycin in immunosuppressed adult mice infected with Cryptosporidium parvum. J. Parasitol. 81, 114-116.

[10] Mancassola, R., Reperant, J.-M., Naciri, M. and Chartier, C. (1995) Chemoprophylaxis of Cryptosporidium parvum infection with paromomycin in kids: an immunological study. Antimicrob. Agents Chemother. 39, 75-78.

[11] Blagburn, B.L., Drain, K.L., Land, T.M., Kinard, R.G., Moore, P.H., Lindsay, D.S., Patrick, D.A., Boykin, D.W. and Tidwell, R.R. (1998) Comparative efficacy evaluation of dicationic carbazole compounds, nitazoxanide, and paromomycin against Cryptosporidium parvum infections in a neonatal mouse model. Antimicrob. Agents Chemother. 42, 28772882.

[12] Bissuel, F., Cotte, L., Rabodonirina, M., Rougier, P., Piens, M.A. and Trepo, C. (1994) Paromomycin: an effective treatment for cryptosporidial diarrhea in patients with AIDS. Clin. Infect. Dis. 18, 447-449.

[13] Roberts, F., Roberts, C.W., Johnson, J.J., Kyle, D.E., Krell, T., Coggins, J.R., Coombs, G.H., Milhous, W.K., Tzipori, S., Ferguson, D.J., Chakrabarti, D. and McLeod, R. (1998) Evidence for the shikimate pathway in apicomplexan parasites. Nature 393, 801-805.

[14] Doyle, P.S., Kanaani, J. and Wang, C.C. (1998) Hypoxanthine, guanine, xanthine phosphoribosyltransferase activity in Cryptosporidium parvum. Exp. Parasitol. 89, 9-15.

[15] Woods, K.M., Nesterenko, M.V. and Upton, S.J. (1996) Efficacy of 101 antimicrobials and other agents on the develop- 
ment of Cryptosporidium parvum in vitro. Ann. Trop. Med. Parasitol. 90, 603-615.

[16] Theodos, C.M., Griffiths, J.K., D'Onfro, J., Fairfield, A. and Tzipori, S. (1998) Efficacy of nitazoxanide against Cryptosporidium parvum in cell culture and in animal models. Antimicrob. Agents Chemother. 42, 1959-1965.

[17] Brasseur, P., Lemeteil, D. and Ballet, J.-J. (1991) Anticryptosporidial drug activity screened with an immunosuppressed rat model. J. Protozool. 38, 230S-231S.

[18] Gao, W.Y., Shirasaka, T., Johns, D.G., Broder, S. and Mitsuya, H. (1993) Differential phosphorylation of azidothymidine, dideoxycytidine, and dideoxyinosine in resting and activated peripheral blood mononuclear cells. J. Clin. Invest. 91, 2326-2333.
[19] Gao, W.Y., Agbaria, R., Driscoll, J.S. and Mitsuya, H. (1994) Divergent anti-human immunodeficiency virus activity and anabolic phosphorylation of $2^{\prime}, 3^{\prime}$-dideoxynucleoside analogs in resting and activated human cells. J. Biol. Chem. 269, 12633-12638.

[20] Vazquez-Padua, M.A., Mayol, N. and Lopez, M. (1995) Uptake and distribution of $2^{\prime}, 3^{\prime}$-dideoxyinosine and its derivatives in a human monocytoid cell line. Cell. Mol. Biol. 41, (Suppl. 1) S113-S119.

[21] Woods, K.M. and Upton, S.J. (1998) Efficacy of select antivirals against Cryptosporidium parvum in vitro. FEMS Microbiol. Lett. 168, 59-63. 